\title{
Reframing customer value from a dominant logics perspective
}

\author{
Tobias Schlager $\cdot$ Peter Maas
}

Received: 30 March 2011 / Accepted: 10 October 2011 / Published online: 27 October 2011

(C) Springer-Verlag 2011

\begin{abstract}
Customer Value (CV) is one of the most crucial concepts in the field of marketing. Literature states that the identification and creation of $\mathrm{CV}$ is decisive for the strategic success of any organization. Moreover, CV was coined a hot research topic in the field of marketing for the years of 2010-2012 by the Marketing Science Institute (2010). However, there is still no clear opinion about the concept per se, as there is currently no accepted CV definition. What is more, since a broad variety of fundamental developments, such as the rise of the service-dominant and customer-dominant logic, touched the CV concept in the past years, there is a need to reflect upon them. Therefore, the article addresses this challenge and analyzes recent developments to provide a common basis for future research. Moreover, the resulting implications for $\mathrm{CV}$ creation are provided. Focal questions that arise when considering $\mathrm{CV}$ include: What is the nature of $\mathrm{CV}$ and how can value be created considering the implications of both logics?
\end{abstract}

Keywords Customer value $\cdot \mathrm{S}-\mathrm{D}$ logic $\cdot \mathrm{C}-\mathrm{D}$ logic $\cdot$ Nature of value $\cdot$ Value creation

\section{Introduction}

Within the past few decades, there has been a broad shift from searching for sources of competitive advantage within a company, to investigating external sources of competi-

\footnotetext{
T. Schlager $(\bowtie) \cdot$ P. Maas

Institute of Insurance Economics, University of St. Gallen,

Kirchlistr. 2, 9010 St. Gallen, Schweiz

e-mail: tobias.schlager@unisg.ch

P. Maas

e-mail: peter.maas@unisg.ch
}

tive advantage (Woodruff 1997; Khalifa 2004; Cleland and Bruno 1996). One of marketing's most fundamental concepts, customer value $(\mathrm{CV})$, recognizes this by placing the focus on the customer. The relevance of $\mathrm{CV}$ is not under discussion, as the creation of $\mathrm{CV}$ is considered the basis for a company's business success (McDougall and Levesque 2000; Porter 1996; Woodruff 1997; Payne and Holt 2001; Huber et al. 2001), central to competitive advantage (Khalifa 2004; Kothandaraman and Wilson 2001; Parasuraman 1997), and directly related to shareholder value (Cleland and Bruno 1996). In 2007, the American Marketing Association (2007) adapted its definition of marketing to reflect the focus on value. More recently, Vargo and Lusch (2008a) defined value as "[...] idiosyncratic, experiential, contextual and meaning laden" (p. 7). However, due to its complexity, there is still much discussion about the meaning of $\mathrm{CV}$, as several definitions have been attached to the term (Smith and Colgate 2007). The semantic heterogeneity is also highlighted by the multitude of different terms that have been used in the context of CV (Voima et al. 2010). Recently, the term customer has even come under discussion (Vargo and Lusch 2004; Woodruff and Flint 2006; Henneberg and Mouzas 2008). Consequently, the marketing literature is still deficient in its understanding of CV (e.g., Woodruff and Flint 2006; Smith and Colgate 2007; Blocker 2011) and calls for further investigation into CV are loudening (Voima et al. 2010).

On top of this deficient understanding, various developments emphasizing the importance of the customer, are increasingly addressed in the literature (Shah et al. 2006; Heinonen et al. 2010; Vargo and Lusch 2004). Two of these developments substantially change the notion of $\mathrm{CV}$, namely the rise of the service-dominant (S-D) and customer-dominant (C-D) logic. There are two primary reasons for the relevance of relating both logics to $\mathrm{CV}$. On the one hand, 
both logics, especially the C-D logic, acknowledges the importance of the customer, and thus, inherently strengthens the focus on the customer and, as a result, the CV concept. On the other hand, the logics comprehensively summarize issues changing and advancing CV (Woodruff and Flint 2006; Voima et al. 2010). We regard the impact on CV as twofold. Clearly, the scope in which CV is considered has risen (Gummesson 2008; Edvardsson et al. 2011; Woodruff and Flint 2006), which makes CV a concept that is even more vague than before. However, one might also argue that the mentioned logics have a large potential to inform, and thus, to further develop the CV concept (e.g., Voima et al. 2010; Woodruff and Flint 2006). As we believe more strongly in the second aspect, we acknowledge the importance of registering the impacts for further enhancing CV.

An initial attempt to outline the implications from the SD logic on CV comes from Woodruff and Flint (2006). The authors mention several important issues, such as the changing role of the customer. Nevertheless, they do not fully take into account recent trends, such as the importance of customer integration, the focus on interactions, and other issues with an impact on $\mathrm{CV}$ that were recently addressed by S-D logic. For instance, a multitude of authors have discussed value and its creation (e.g., Voima et al. 2010; Vargo et al. 2008; Payne et al. 2008; Lusch and Vargo 2006b; Heinonen et al. 2010; Grönroos 2011; Grönroos 2008; Grönroos and Ravald 2011). By doing so, they implicitly advance CV without being directly related to $\mathrm{CV}$. What is more, until now, no article has explicitly addressed the implications of the most recent discussions for $\mathrm{CV}$, neither of the S-D, nor of the C-D logic. Intuitively, the following question arises: What impact do both logics have on the CV concept?

The primary objective of our paper is to fill this gap in the literature and to provide a basis for further research by evaluating the influences of the S-D and C-D logic (Vargo and Lusch 2008a; Heinonen et al. 2010; Vargo and Lusch 2004). In particular, our article addresses the following research questions: How did both logics change the understanding of CV? As implications regarding the creation of value can primarily be recognized by taking into account the S-D and C-D logic's perspectives, we also discuss what this means for value creation. In doing so, we make contributions to the literature in three areas of $\mathrm{CV}$ :

- The nature of CV

- The ways of, and capabilities needed for, creating CV

- The scope in which the nature and creation of $\mathrm{CV}$ is considered

The scope of this paper is limited to the nature and the creation of $\mathrm{CV}$, as our primary objective is to provide a starting point for other scholars. Neither do we enter in the current discussion, like the one regarding the roles within value creation (e.g., Grönroos 2011), nor do we aim to provide a

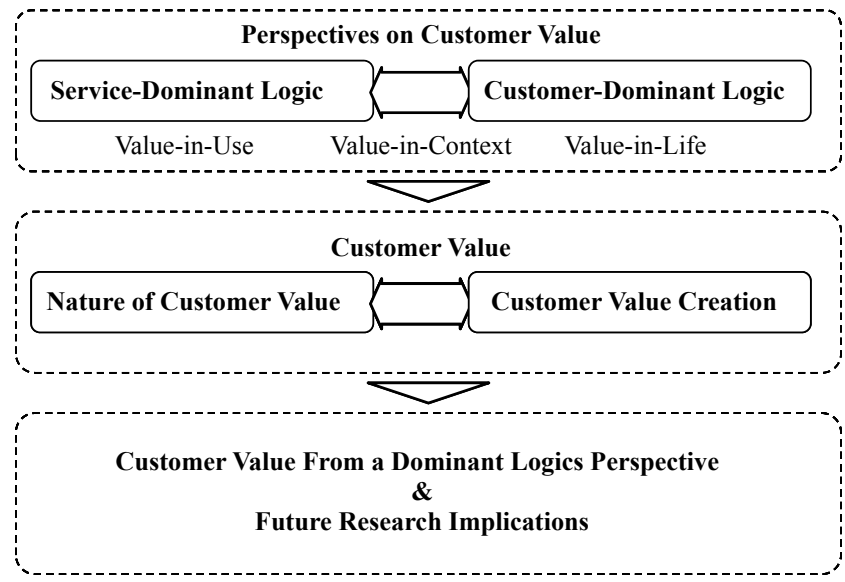

Fig. 1 The structure of the paper

new conceptualization regarding $\mathrm{CV}$, as we only focus on the changes implied by the S-D and C-D logic.

The remainder of the article is organized as follows (Fig. 1). First, the S-D and C-D logic are outlined, with focus on the resulting changes in current value paradigms (i.e., from value-in-exchange to value-in-use). Next, we discuss the nature of $\mathrm{CV}$ and the range of $\mathrm{CV}$ considerations as major changes and enhancements are proposed by both logics. As a primary focus of the S-D and C-D logic is laid on value creation, we outline ways of creating $\mathrm{CV}$ from this novel perspective in a third step. Finally, a model of CV, from the logics perspective, is established and briefly delineated by summarizing the key points. While each section of the article emphasizes the current state of the literature, we broadly outline avenues for future research, as well as theoretical and practical implications, as we strive to provide a common parting ground.

\section{The dominant logics and value concepts}

Two recently developed logics that substantially changed the understanding of marketing are the S-D and the C-D logic ${ }^{1}$. As value considerations that are more general in nature and that are dominantly discussed in the marketing literature, namely value-in-use, value-in-context and value-in-life, are closely linked to both logics, we discuss them after presenting the logics' primary thoughts.

The S-D logic was initiated in 2004 by the award-winning article 'Evolving to a new dominant logic for marketing' (Vargo and Lusch 2004). It accentuates a shift away from goods to service provision, lays a focus on intangible resources, the co-creation of value by the customer, and the

\footnotetext{
${ }^{1}$ When using 'the logics', we refer to both upcoming logics as in a multitude of aspects, as they appear to have similar consequences. In case they differ, we only refer to the applying logic.
} 
notion of interaction and relationships, and proposes a phenomenological facet of value (e.g., Vargo and Lusch 2006). Woodruff and Flint (2006) back the importance of the S-D logic for $\mathrm{CV}$ by outlining several issues relevant for CV. As a result, an enormous impact on $\mathrm{CV}$ regarding its nature and value creation, in general, can be acknowledged (Woodruff and Flint 2006; Vargo and Lusch 2004, 2006, 2008a).

Recently, the C-D logic appeared in the literature picking up thoughts of S-D logic, as well as passing criticism on the S-D logic: According to the C-D logic, the S-D logic is still a supplier-dominant logic. Arguing so, the C-D logic even goes further in positioning the customer in the center by shifting the focus from the company's processes to the customer's reality and history (Heinonen et al. 2010). The primary distinction between both logics is the point of view. While the S-D logic is supplier focused, the C-D logic refers to the customer as the starting points of most relevant considerations. For instance, under the C-D logic, service providers need to enhance their understanding of the customers history, objectives and goals, followed by using services (Wikner 2010; Voima et al. 2010). From a $\mathrm{CV}$ perspective, we regard this inherent focus on the customer as useful, even though the C-D logic has primarily been applied to a service context. Thus, although only a handful of articles have appeared regarding this logic, we apply its notions on $\mathrm{CV}$.

Both previously-mentioned logics, especially the rise of the S-D logic, have a fundamental impact on the development of CV (Woodruff and Flint 2006; Voima et al. 2010). What they have in common is that they both emphasize the importance of the CV concept and impose foundational challenges for the CV concept (Vargo and Lusch 2008a; Heinonen et al. 2010). More specifically, they enhance discussions about value considerations that are closely tied to the nature of $\mathrm{CV}$, and thus, appear as highly relevant for the presented article.

Broadly discussed and commonly accepted is the shift from value-in-exchange to value-in-use (e.g., Ravald and Grönroos 1996; Ballantyne and Varey 2006; Normann and Ramirez 1993; Holbrook 1994). Similarly, this development is strongly underlined by both logics, as both even further develop the notion of value-in-use. Newer considerations, substantially fostered by the S-D and C-D logic, are presented by the value-in-context and value-in-life (Voima et al. 2010; Vargo et al. 2008; Edvardsson et al. 2011). Thus, the three are briefly outlined in order to grasp their ideas.

Value-in-use expresses the idea that value is created by using a product or service, rather than by producing the product or service (e.g., Lusch et al. 2007; Vargo and Lusch 2004), which constitutes one key assumption of the S-D logic (e.g., Edvardsson et al. 2011). Although similar notions have already appeared in past studies (Vandermerwe 1996; Levitt 1986; Alderson 1957), the idea has re-gained relevance (e.g., Heinonen et al. 2010). Therefore, its implications on $\mathrm{CV}$, especially regarding the understanding of $\mathrm{CV}$ and the methods of value creation, need to be registered. This idea is advanced by value-in-context, which lays an emphasis on the role of "[...] other market-facing, public, and private resources [...]" (Merz et al. 2009, p. 330). In line with this, a notable article emphasizes the customers' embeddedness into a social context by applying social construction theories (Edvardsson et al. 2011), while others mention complexity theory as a theoretical underpinning for a similar notion (Gummesson 2008). Nevertheless, valuein-context has already received criticism as some scholars consider the idea as static (Grönroos and Ravald 2011). The C-D logic recognizes this by emphasizing the highly dynamic and multi-contextual reality and life of the customer, implying a significant emphasis on the customer's experiences and history, especially in service settings. As a result, the notion of value-in-life is proposed (Voima et al. 2010). Whether value-in-context or value-in-life is more appropriate is not yet commonly agreed upon. However, as this brief outline illustrates, substantial influences on value considerations are presented by the emergence of the S-D and C-D logic which, in turn, changes the understanding of CV.

\section{Customer value's nature}

As both logics influence the nature of $\mathrm{CV}$, which has already been vague before, there is a need to address them. Up to now, several facets of CV have repeatedly appeared in the literature regarding $\mathrm{CV}$. Among those, $\mathrm{CV}$ is described as being a trade-off between benefits and sacrifices (Ulaga 2003; Zeithaml 1988; Gale 1994), subjective (Nasution and Mavondo 2008; Ulaga 2003; Kortge and Okonkwo 1993; Vargo and Lusch 2004), multi-dimensional (Matzler 2000; Ulaga 2003; Holbrook 2005; Sweeney and Soutar 2001) and relativistic (Gale 1994; Holbrook 1994, 2006). Moreover, it has been delineated as context-specific and experiential (Holbrook 2005). Although the ideas of several facets have been picked up by both logics (i.e., CV's context-specific and experiential nature), substantial changes can be recognized which are summarized in the following section. Figure 2 presents the development from the classical understanding of CV to an understanding from a S-D and C-D logic's per-

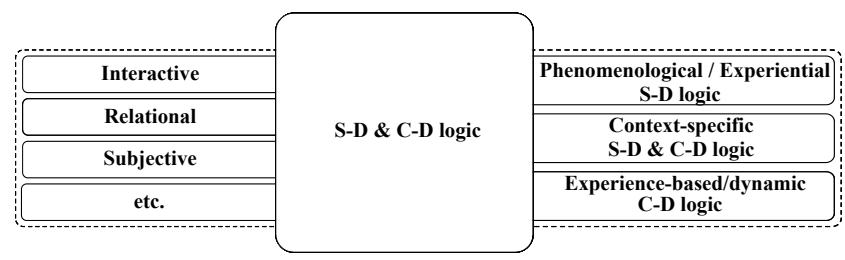

Fig. 2 The changing nature of $\mathrm{CV}$ 
spective; each facet is assigned the logic that mostly emphasizes its notion.

\section{Phenomenological and experiential facet}

According to the S-D logic, a shift towards emphasizing the experiential and phenomenological facet of CV can be acknowledged by the shift towards emphasizing the experiential and phenomenological facet of CV (Vargo and Lusch 2004; Woodruff and Flint 2006). Both terms, 'experiential' and 'phenomenological', emphasize the co-creation role of the customer (Vargo and Lusch 2008a). From this understanding, 'experience' does not refer to the customer's past experiences, it rather describes the perishability inherent to CV (Vargo and Lusch 2008b). This underscores that value cannot be inventoried and is not created solely by the company which is, however, not new to the literature.

Prahalad and Ramaswamy (2004b, p. 137) use the term in a similar manner and emphasize the shift toward experiences as they state that "[...] value is now centered in the experiences of consumers". Similarly, even earlier contributions suggest an experiential perspective that includes symbolic, hedonic and aesthetic aspects in the consumption process (Babin et al. 1994; Hirschmann and Holbrook 1982). Although both terms are still discussed, 'phenomenological' has recently been preferred, as 'experiential' implies several other meanings, such as a focus on the past. In contrast, phenomenological emphasizes the idiosyncratic determination of value (Vargo and Lusch 2008a) without implying a focus on the past. This accentuates that companies and customers have equal roles in value determination, as the process among both parties is emphasized, while the oldfashioned notion of value being provided by the company is no longer supported. The idea gets explicitly expressed by highlighting interactions when considering the creation of $\mathrm{CV}$ as the S-D logic does.

Woodruff and Flint (2006) explain the phenomenological nature of $\mathrm{CV}$ as context-specific, interactive, and attached with meanings. ${ }^{2}$ The $\mathrm{C}-\mathrm{D}$ logic accepts that interactions facilitate the creation of value, however, contrary to the S-D logic's supplier-oriented approach, it emphasizes that it is the customer who ultimately determines the value created. In doing so, the $\mathrm{C}-\mathrm{D}$ logic stresses that other processes not directly related to interactions also need to be considered (Heinonen et al. 2010).

The interactive aspect implied in the term 'phenomenological' is closely linked to another important characteristic.

\footnotetext{
${ }^{2}$ Although Woodruff and Flint's (2006) interpretation of the term 'phenomenological' mentions context specificity, we treat this as a separate issue, as it has not been clearly delineated by the authors. Moreover, a multitude of other articles have further developed the meaning of 'context-specific' without referring to it as the phenomenological aspect. Hence, we discuss this issue separately.
}

Seeing the customer in a constant and interactive process with other actors, such as companies and other customers, bolds the increasing focus on relational aspects, which is therefore underpinned in the S-D (Vargo and Lusch 2004) and C-D logic (Heinonen et al. 2009, 2010). Hence, an increasing focus on relationships, rather than on transactions, is suggested (Vargo and Lusch 2008b). According to both logics, the customer is engaged in multiple relationships, also to actors other than the company. The old-fashioned view on relational aspects as being dyadic does not seem to be supportable anymore (e.g., Voima et al. 2010). Intuitively, the customer now appears as being embedded within a context of other value determining resources and actors.

\section{Context-specific facet}

Following the notion of multiple relationships, the literature acknowledges the important role of the customer's external and social context in the assessment of CV (Voima et al. 2010; Edvardsson et al. 2011). In doing so, the idea of the customer, just like the company, being embedded in a system of other actors is expressed (e.g., Vargo and Lusch 2004). In this complex system, the customer acts as a resource integrator, simultaneously combining various resources for value creation. This implies that the customer uses his/her own resources (i.e., knowledge and skills) and the resources of other actors. Hence, CV is dependent on a network of competences and resources.

While the previous literature has accepted CV's dependence on the context, the S-D and C-D logic have strongly emphasized and further developed this idea. One of the first guiding conceptual articles was put forth by Edvardsson et al. (2011). Social construction theories are applied to stress the importance of the social context for value creation under the S-D logic. On this basis, four propositions are delineated, two of which strongly underline the importance of the social dimension of value: "Value has a collective and intersubjective dimension and should be understood as value-in-socialcontext" (p. 333) and "[...] the way in which resources are assessed depends on the social context" (p. 334). It can be concluded that research efforts begin to adapt a more differentiated point of view, which includes the social context as an important variable for the determination of value.

The C-D logic argues in a similar manner, stating that the dyadic approach that was historically used is not enough to display the complex construct of CV (e.g., Voima et al. 2010). Hence, this logic also highlights that the customer is socially-embedded, interacting with other groups, such as other customers. Compared to the S-D logic, the C-D logic more strongly emphasizes the customer's point of view. An even higher focus is laid on the customer, and thus, on his/ her specific context. In summary, while the social context 
gets emphasized by both logics, the C-D logic fully takes in the customer's perspective (Voima et al. 2010).

\section{Experience-based facet}

Contrary to the experiential and phenomenological nature, the facet of $\mathrm{CV}$ that we term 'experience-based' refers to the past experiences of customers. As Voima et al. (2010, p. 4) states, "[...] the starting point is the customer's reality and life". Value is therefore regarded as part of the dynamically-constructed and multi-framed reality of each customer. Although earlier contributions also recognized similar aspects (i.e., by terming it 'subjective', Woodruff 1997), the focus on the customer's history, and thus, the experiencebased nature of $\mathrm{CV}$ was especially emphasized by the CD logic. In this light, value is termed 'value-in-life', which better explains the holistic view of the customer's life than value-in-context (Voima et al. 2010). With this focus on the internal context, it is emphasized that value formation is extended beyond the interactive processes and the visibility of companies and includes the customer's mental processes (Heinonen et al. 2010), resulting in an increase in complexity as now the customer's history is also considered.

A facet of the experience-based nature of value is its dynamic aspect, which expresses the constantly changing and adapting evaluations of what customer's value. It focuses on changes in customer-desired value (Blocker and Flint $2007 \mathrm{a}, \mathrm{b})$. Still, there is disagreement among researchers and practitioners regarding how (Beverland and Lockshin 2003, 2004) and why it occurs (Flint and Woodruff 2001), which underpins its underdeveloped state (Blocker and Flint 2007b). This issue is more relevant than ever, as the customer's value perceptions tend to change at a revolutionary speed within today's quickly changing environment (Flint et al. 2002). Consequently, failing to respect the dynamic may directly harm a company's financial performance (Blocker and Flint 2007b; Grieve and Ortiz 2003). Additionally, Blocker and Flint (2007b) re-emphasize the importance of knowledge about what customers will value in the future for building and maintaining a sustainable advantage. As this research stream is closely connected to the experiencebased facet, it is especially the C-D logic which draws attention to the dynamic and ever-changing nature of CV (Voima et al. 2010), partly supported by the S-D logic (Madhavaram and Hunt 2008).

\section{Customer value creation}

The S-D and C-D logic emphasize a fundamentally changed perspective on value and value creation. Intuitively resulting from discussions regarding CV's nature is the question: How is CV creation considering this new standpoint? We address this question by recognizing that former frameworks (i.e. the one put forth by Smith and Colgate 2007) have yet become outdated in the light of S-D and C-D logic. What is worthwhile to note is that discussions about the role of the company, as well as the customer in value creation, have appeared (Edvardsson et al. 2011; Gummesson 2008; Grönroos and Ravald 2011). We do not directly enter these however, but instead reflect implications from the changing nature on a general level for two reasons. First, by drawing implications on value creation on a higher level, we aim to provide a basis for enhancing this discussion, while entering these would go beyond the scope of this paper. Second, we regard discussions as highly dependent on the point of view and the context (i.e., product vs. service context, Gummesson 2008) which we do not discuss either. Thus, we take this avenue and address questions which are more general in nature. More specifically, we identified interactions, a focus on relationships, and holistic marketing processes as responsible for value creation.

\section{Interaction}

The recent literature concerning the S-D logic and value-inuse places a special emphasis on company-customer interactions as source of CV. Although interactions have already been acknowledged as source of value by other frameworks (e.g., Smith and Colgate 2007), the notion is further enhanced. Emphasizing interactions as a crucial concept from a S-D logic perspective, Grönroos and Ravald (2011, p. 12) define interactions as "[...] a mutual or reciprocal action where two or more parties have an effect upon each other". On this basis, it is argued that through interactive processes, companies can get actively involved in creating experiential value. Other contributions confirm this by seeing interactions as having the ability to promote experiential and phenomenological value (Ballantyne and Varey 2006). Similarly, scholars assess that interactions provide the basis for forming the customers' preferences (Mathwick et al. 2002). The importance of the company-customer interaction is underlined by the ability to facilitate value and to influence $\mathrm{CV}$ perceptions. As a result, it is broadly accepted that the customers' creation of value is catalyzed through interactions (Grönroos 2009; Grönroos and Ravald 2009, 2011; Tynan et al. 2010). Although the difference between services and goods environments is still discussed, it appears that interactions being especially important in a service-context is an accepted concept. From the companies' perspective, this is due to the multitude of opportunities for co-creating value with the customer when acting within the customer's sphere (Grönroos 2008).

One other issue that comes into play is the superior ability to sense the customers' needs within interactions (Tynan et al. 2010). Although interactions per se are especially consi- 
dered by the S-D logic, they may also provide a source of indepth knowledge about the customer and his/her life, which is rather emphasized by the C-D logic. More information can be generated, and as a result, companies can develop better insights about their customers. This issue's importance is underscored by the C-D logic; therefore, we also argue that from a C-D logic point of view that companycustomer interactions are highly relevant.

\section{Integration}

Closely connected to, but still distinct from, interactions as source of CV is the integration of resources (e.g., Mele et al. 2010). This includes the integration of the customers' resources which refers to providing customers with the opportunity to participate within the companies processes (e.g., Möller 2006). Integrating the resources of customers and companies is treated as prerequisite for interactions. As Grönroos and Ravald (2011, p. 11) state: "An inherent aspect of interaction is connectivity", i.e., the parties involved are in some contact with each other. With the term 'connectivity', the authors emphasize the integration of the companies' and the customers' resources. The importance of the integration of the companies' and customers' resources in the value creation process is strongly emphasized by the S-D logic (e.g., Vargo and Lusch 2004). In a similar manner, Edvardsson et al. (2010) refers to 'getting close to customers' by customer integration.

We argue that this proximity to the customer partly takes in an avenue that is emphasized by the C-D logic. The C-D logic accepts the importance of interactions, but even goes one step further by also seeing "[...] other activities and experiences [...]" (Heinonen et al. 2010, p. 535) that are not directly connected to service-related interactions. From this position, customer processes which are not controlled by a company are considered as a highly relevant part within value creation. Hence, the challenge that needs to be addressed is discovering the underlying issues which cannot be easily recognized by a company. When the customer's life is brought into the focus of value creation, an in-depth knowledge of the customer becomes necessary. As Heinonen et al. $(2010$, p. 538) note: "[...] we first need to understand the customers' lives [...]" which renders the importance of a fine-grained understanding of the customer. One way to gain this depth of understanding of the customer is integrating customers into the company's processes. The aim of integration may therefore not only be the creation of interactions, but also the achievement of profound customer insights that go beyond insights gained by traditional marketing research methods. Hence, integration can also be considered a way for getting deep customer insights regarding what the C-D logic describes as 'value-in-life'.
We conclude by stating that the benefits of customer integration are twofold. On the one hand, interactions are generated, which in turn, are considered a source of CV. On the other hand, it has the ability to generate in-depth knowledge of the customer, which may provide insights regarding value-in-life considerations and, as a result, for aligning future company actions.

Focus on relationships

When facing notions like interaction and integration, it becomes obvious that relationships play an important role within value creation, which is a concept that is extensively highlighted by both logics (Vargo and Lusch 2004; Voima et al. 2010; Woodruff and Flint 2006). Both interaction and integration can be considered a means to the end, which is relational value. This is due to the important role of interactions in facilitating relationships (Payne et al. 2008; Prahalad and Ramaswamy 2004a; Sandström et al. 2008; Vargo and Lusch 2004). Generally, it is proposed that relationships themselves are a source of value (e.g., Howden and Pressey 2008; Lindgreen and Wynstra 2005); relational benefits and sacrifices need to be considered in the value formation process (Grönroos 1997; Payne and Holt 2001; Ravald and Grönroos 1996; Ulaga and Eggert 2005). In this light, trust and risk avoidance are especially considered focal constructs (e.g., Lindgreen and Wynstra 2005). Most commonly, the literature assesses the value that emerges in relationships between companies and customers (Ulaga and Eggert 2005, 2006b), but also the relationship between customers and customers (Voima et al. 2010; Edvardsson et al. 2011) and between customers and brands (Payne et al. 2009).

Similarly to the explanation regarding the 'integration of the customer into the company's processes', we argue about the focus on relationships. Relationships are a source of value, but they also provide companies with a good understanding of the customer and his/her needs. A multitude of studies have connected relationships with the customers' willingness to provide information (Lapierre 2000; Wuyts and Geyskens 2005). Even intimate information regarding the customer's life can be sensed within a close relationship (Grayson 2007; Wong et al. 2005). Hence, more accurate information can be gained concerning what customers value considering their life and experiences. Therefore, we propose that the relevance of relationships can also be considered as an important part in fitting the companies actions and offers to the customer's life, stressed by the C-D logic.

In summary, although the relational facet is not new to the literature, the focus on interaction and integration augments the importance of relationships from both logics points of view. Thus, focusing on relationships can be proposed as one fruitful way of creating value in a S-D and C-D logic context. 
Holistic marketing processes

The customer's relationships to other actors, and thus, the notion of customers being embedded within a highly complex context, is emphasized by the two discussed logics. Again, one catalyst is the rise of the S-D logic that emphasizes the customer as resource integrator also using other resources for value creation (e.g., Vargo and Lusch 2004). Consistent with this, developments, such as shift to the empowered and active customers (Payne et al. 2009; Vargo and Lusch 2004; Edvardsson et al. 2011), customer-customer and social interactions, have rapidly gained importance. A similar argument holds true from a C-D logic point of view, which emphasizes processes in value creation that are not directly related to services (Heinonen et al. 2009). Therefore, we briefly review processes that have been discussed for creating value in the face of the complexity delineated by the S-D and C-D logic perspectives. In this light, Edvardsson et al. (2011) emphasized the customers' context as a source of value for the customer. That is, appearing more valuable to the social context enhances the individuals' value perception. Hence, the relevant question to ask becomes: How can value creation through the social context be enhanced? We argue that an initial answer to this question can be found in the already discovered constructs and propose that branding provides a fruitful way to enhance value creation within a complex social context, as we will outline below.

Brodie et al. (2009) summarized previous articles about the influence of brand-related constructs on perceived customer quality and perceived value. Similarly, other articles have discussed the relationships between $\mathrm{CV}$ and branding (Brodie et al. 2009; Tynan et al. 2010; Nasution and Mavondo 2008; Payne et al. 2009). A positive brand image indirectly enhances value-in-use (Strandvik and Rindell 2010), a development which can be considered as one of the assumptions of the S-D and C-D logic. Similarly, the social context is emphasized by both logics; consumers form relationships with brands that reflect their social relationships (Payne et al. 2009), and thus, reflect the customer's accumulated experiences and knowledge. Brands therefore act as comprehensive facilitator of CV. Although earlier contributions have argued that resources, like brands, may constitute a source of value (e.g., Möller 2001; Srivastava et al. 2001; Erdem and Swait 1998; Dawar and Parker 1994), the idea of relating branding and company images to $\mathrm{CV}$ is a more recent phenomenon and has become increasingly popular. For instance, the importance of experiential value is emphasized by both logics (Vargo and Lusch 2004; Voima et al. 2010). Cova and Pace (2006) closely relate the research on communities to branding by mentioning brand communities and brand tribes. Accordingly, brand communities and tribes may leverage a brand's symbolic value, and therefore, provide a source of $\mathrm{CV}$. Consistent with this, Cretu and Bro- die (2007) confirm through their research that official and unofficial brand communities may be a source of $\mathrm{CV}$, an idea recently supported by the literature (Tynan et al. 2010). Thus, we state that brands and brand communities facilitate the creation of value regarding the customers' social context.

However, recently appeared literature advances to a more general level, considering brands that reflect the customer's social context as a source of value creation. As a result of the network perspective on customer and company side respectively, many-to-many marketing, rather than a dyadic view with a customer focus, is proposed (Gummesson 2008; Gummesson et al. 2010). With many-to-many marketing, the variety of resources that are integrated for creating value, on the customer as well as on the company side, are outlined. Accordingly, all of them need to be aligned in order to foster value creation (Henneberg and Mouzas 2008). Tying up with many-to-many marketing, the S-D logic acknowledges the company's function as resource integrator (e.g., Vargo and Lusch 2004; Edvardsson et al. 2011). As a result, the important role of networks on the company side is underlined (Mele et al. 2010) and the idea of value networks, implying a multi-directional focus on relationships and interactions, is becoming increasingly accepted (Ulaga and Eggert 2006a; Lusch et al. 2010; Edvardsson et al. 2011). In line with this notion, the final consumer's role is described as network customer (Henneberg and Mouzas 2008). Mirroring this discussion on the customer-side, a term that gets increasingly popular is 'network value', referring to all benefits and sacrifices that network partners create through actions and relationships (Mele et al. 2010). Accordingly, $\mathrm{CV}$ is the desirable outcome of value networks which provides a holistic view on CV not only considering the value-added (Srivastava and Singh 2010). From a S-D logic perspective, company networks may be the source for providing an environment that fosters the co-creation of value by the customer (Sandström et al. 2008). Although the idea of networks in terms of value creation is certainly not new to the literature, the S-D and C-D logic certainly raise its importance in terms of creating value. By doing so, an organization that extensively engages in network considerations with the customer being centered in the middle of the objectives can enhance the facilitation of $\mathrm{CV}$.

We conclude by stating that several opportunities for enhancing a favorable customer context exist. On the highest level, a well-defined many-to-many marketing strategy, which constitutes a complex process, is proposed. Each part of the process needs to be integrated and aligned. A more specific way of positively influencing the customer's context is to enhance the formation of customer communities and to engage in successful branding as the context is influenced. We term the holistic efforts that provide the customer with a value-enhancing context as 'holistic marketing processes'. 


\section{A framework for customer value}

Following the aim of our paper, which is to register influences of dominant logics on $\mathrm{CV}$, on the one hand, we addressed the nature of $\mathrm{CV}$. On the other hand, we mirrored the nature in terms of implications for $\mathrm{CV}$ creation. The model shown in Fig. 3 underpins the paper's idea, which is to draw recommendations regarding value creation based on the nature of $\mathrm{CV}$. Hence, we connect both sides, the nature of value with the respective source of value creation. As we have already comprehensively explained both issues, we outline the model on a high level.

By means of the presented model, we strongly emphasize the customers' and the company's intertwined roles. This is done by displaying, for instance, the focus on the interactions with, and integration of, the customer (Payne et al. 2008; Grönroos 2011). Furthermore, the embeddedness of both parties in a broader context underpins the complexity that is proposed by recent research on value (Edvardsson et al. 2011; Gummesson 2008), which is closely connected to the variety of relationships that exist. Adding to this, we include the customers' history within the considerations, proposed by the C-D logic (Voima et al. 2010). The network focus on the company side, with the underlying idea of many-tomany marketing, is regarded as necessary within an interconnected setting to facilitate value creation. At the bottom of Fig. 3, the underlying discussions about value are shown, which form the basis for explicating $\mathrm{CV}$ and relating it to value creation. The increasing complexity of $\mathrm{CV}$ considerations is shown first as value-in-use, then value-in-context and finally value-in-life. Value-in-life and the experiencebased facet underpin the importance of in-depth knowledge, which is displayed by insights resulting from interactions, customer integration and close relationships. Regarding the value-in-life, practical approaches still need to be found, as currently no research is dedicated to this enhancement of other types of value.

Certainly, the model remains abstract and does not display all of the complex processes within the area of $\mathrm{CV}$ and the ways of creating $\mathrm{CV}$, however, we argue that the most relevant implications of our manuscript, and thus, of both logics, are condensed to a model.

\section{Discussion}

Until today, no single opinion has been established regarding CV (Graf and Maas 2008; Smith and Colgate 2007; Gallarza and Gil Saura 2006). Within this vague context of $\mathrm{CV}$, we recognize the ambiguous influence of both logics that changes marketing literature. On the one hand, the S$\mathrm{D}$ and C-D logic add complexity to CV, making it an even more unseizable concept, while on the other hand, the logics enrich the understanding of the concept as CV is inherently compatible with the ideas of both logics (Voima et al. 2010; Woodruff and Flint 2006). As we believe in the second issue, we reframed the considerations about $\mathrm{CV}$ from the perspective of currently discussed logics. We argue that by doing so, we provide more clarity for the concept of CV. For instance, our article addresses the embeddedness of both,

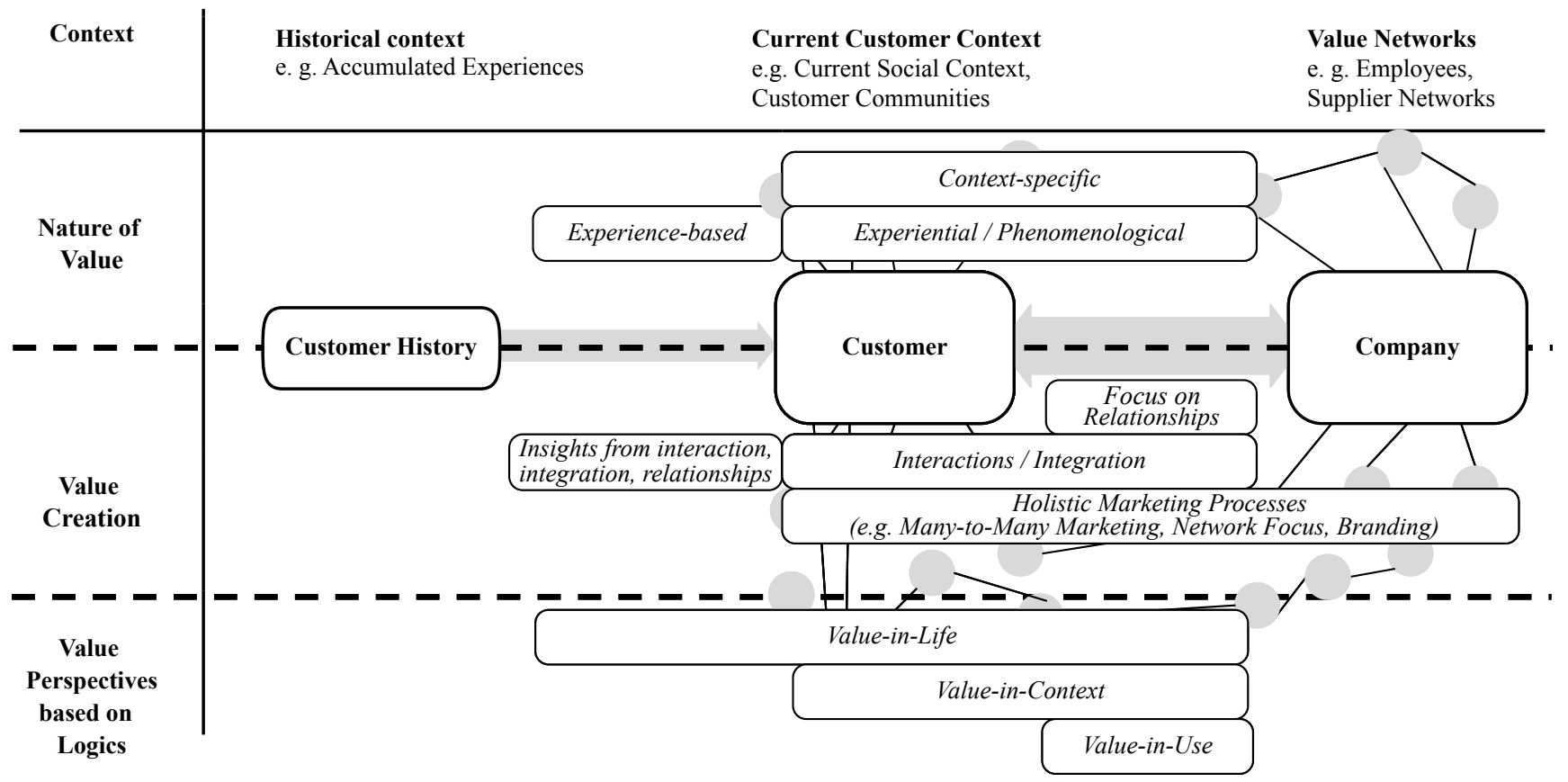

Fig. 3 A Framework for customer value from a dominant logics perspective 
the customer and the company, in the light of value creation. Moreover, the novelty and relatedness of both logics to the value concept strongly emphasizes the relevance of our paper: There is a clear need to reflect their impacts on the CV literature.

One might argue about including the C-D logic as only few contributions have been made so far. However, we see two important reasons for doing so. Firstly, its thoughts are not completely new to the literature, as the considerations of the C-D logic build upon well-established concepts (i.e., the inherent customer focus, Drucker $1974 \mathrm{cf}$. Heinonen et al. 2010). Secondly, as previously outlined, we comply with articles concerning the C-D logic by arguing that its ideas further refine the S-D logic with a focus on the customer (Heinonen et al. 2010; Voima et al. 2010), and thus, has the potential to further inform the CV literature. In this regard, the opinion of researchers arguing in favor of a C-D logic state that the S-D logic is still deficient in several points (Heinonen et al. 2009); these are included in our manuscript.

An issue that is still under discussion in the value literature is the question of who is the value creator at all (e.g., Gummesson 2008; Lusch and Vargo 2006a; Grönroos 2008). On purpose we did not enter this discussion because the objective of our paper was to inform the CV literature with what is certain to date and would have exceeded the scope of the presented article. Hence, we state that who creates value still needs to be reviewed by a multitude of articles. Consequently, we acknowledge that, in terms of other issues, research still has to be conducted to enhance the understanding of $\mathrm{CV}$.

Finally as the nature of $\mathrm{CV}$, such as the focus on the customer's history, context and multiple relationships, changes, the scope in which CV is considered has substantially increased (Heinonen et al. 2010; Voima et al. 2010). Considering this, an important step for the development of CV is pointed out: not only companies, but increasingly, customers and their interactions with other actors are considered relevant for CV (Edvardsson et al. 2011). The literature still needs to determine whether one can translate these conceptual suggestions in practical advice, which we believe is accentuated by our practical implications.

\section{Theoretical and managerial implications}

Our conceptual article entails several theoretical and managerial implications. The most important implication for scholarly research is the common starting point that we aimed at providing. Based on our article, the multi-facetted nature of $\mathrm{CV}$, which has been described by a broad variety of terms (e.g., subjective, interactive), is condensed to mainly three facets that appear to be very important from the perspective of the two dominant logics. Consequently, more clarity is provided which may foster further research and, in turn, makes the concept more attractive. Moreover, we argue that $\mathrm{CV}$ is further enhanced by our manuscript and the conceptual framework we developed.

Although ongoing discussions (e.g., Möller 2006; Voima et al. 2010; Grönroos 2008) coin the current literature on $\mathrm{CV}$ formation, and thus, affect $\mathrm{CV}$ literature as such, we argue that several commonalities can be determined in both logics' implications on CV. For instance, both emphasize the value-in-context; however, the C-D logic accentuates the importance of the customers' lives, tagged as valuein-life. Thus, we also contribute to the literature regarding both logics. In line with arguing for some commonalities, we need to emphasize that implications from S-D and C-D logic might lead to different conclusions in some areas. The primary distinction is the C-D logic's focus on the customer's point of view, while the S-D logic still argues from a supplier perspective (e.g., Voima et al. 2010). Thus, articles regarding $\mathrm{CV}$ might come to a different conclusion based on the perspective applied. Researchers shall thoroughly evaluate whether to argue from a S-D logic or a C-D logic point of view. For instance, when focusing on the customer's past in determining $\mathrm{CV}$, one may be better advised to apply a C-D logic, rather than an S-D logic approach. Whether the literature will reach a consensus is still to be determined by future articles, however, we believe that this article provides a solid basis to start from.

Finally, a primary implication of the presented article is the explicit emphasis of the customer's, as well as the company's embeddedness in a complex context. This notion has the potential to guide researchers in the discussion about value formation and to what degree the value can be determined by companies (Vargo and Lusch 2008b; Grönroos 2008).

Besides the suggested theoretical implications, we propose that the presented article also has the potential to further inform practitioners. In the following, we illustrate the practical value by means of two areas. First, we suggest that the focus on interactions, as mainly emphasized by the SD logic, highlights the importance of outstanding performance when interacting with customers. This, for instance, entails a thoughtful employee selection and training (e.g., Brodie 2009), as it is mostly the customer-contact personnel that is interacting with the customers. The aforementioned suggestion is similarly valid for generating insights about customers and their (often not articulated) needs. In terms of generating customer insights, implications derived from the S-D logic might differ from the ones generated by the C-D logic, as for instance, mainly the latter logic emphasizes the importance of value-in-life, while the former one, to date, does not get explicit about this point (e.g., Voima et al. 2010). Here, well-trained personnel, in combination with routines that make the knowledge about customers expli- 
cit within a company (i.e., systems with detailed customer records), enables the generation of insights, which in turn, can guide companies in supporting $\mathrm{CV}$ creation. Again, we want to stress that this recommendation illustrates that the S-D and C-D logic can differ in their implications.

The second managerial implication to be stressed concerns value-in-context, which is supported by both logics. Although companies are challenged by the resulting complexity, they can use the interconnected world to more effectively communicate with customers. For instance, Web 2.0 strategies can easily be adapted, which makes reaching targeted customer groups easier. On the other hand, the customers' social environment partly determines value creation (e.g., Edvardsson et al. 2011), strongly emphasizing that companies need to engage in consistent messages via all potential ways for reaching a customer.

\section{Future research}

Clearly, a lot of articles have discussed the nature and creation of $\mathrm{CV}$ within the last decade. Nevertheless, further research is needed to enhance the understanding of the concept. For instance, the phenomenological nature of CV still calls for further research, as discussions around the S-D logic are still ongoing (e.g., Mele et al. 2010). For example, the influence of companies is questioned when value is phenomenological in nature (Heinonen et al. 2009). As these valid issues arise, it becomes obvious that it still remains unclear what "[...] uniquely and phenomenologically determined by the customer" (Vargo and Lusch 2008a, p. 7) means. Thus, creating value from a phenomenological perspective needs to be investigated more extensively. However, the importance of use-situations has broadly been overlooked by research on $\mathrm{CV}$. Therefore, we suggest that considering co-creation opportunities may enrich the current literature of $\mathrm{CV}$ in order to better express the notion of CV. In line with this argument is that the literature on the creation of CV has not profoundly evaluated the role of customer integration and interaction, most commonly, only specific issues have been assessed (e.g., Mele et al. 2010). Initial research may evaluate the influence that providing opportunities for interaction have on the evaluations of CV. From this starting point, scholars might enhance research on this issue and approach more detailed research questions.

Similarly, the appearance of value-in-context and valuein-life implies that a broad variety of unconsidered factors, such as the customer's life or external factors, provides the basis for the value assessment (Heinonen et al. 2010; Edvardsson et al. 2011). It is stated that the customer is embedded within a social network which has so far only been proposed conceptually (Voima et al. 2010; Edvardsson et al. 2011). Thus, we propose to further enhance recently appeared approaches, such as the one of Edvardsson et al. (2011). Only few research has been conducted within this area. Edvardsson et al. (2011) also suggest a combination of research approaches. We underpin this, as this might help triangulating the first constructs for research the customers social embeddedness. Empirical approaches to the customer's evaluation of value in the light of a social-context can determine its importance and inform other scholars. This is certainly valid when it comes to value creation by means of the social context. In this point, there is still a gap within the literature regarding the indirect creation of $\mathrm{CV}$ as, for example, only few empirical studies exist up to now (Edvardsson et al. 2011). On the company side, one question to be asked might be: How can companies effectively influence the social context the customer is embedded in? In our manuscript, we provided some hints to doing so; nevertheless, research on this topic is still at the beginning regarding this issue. We also recommend that researchers begin evaluating the fit of concepts used in other fields, such as sociology (Heinonen et al. 2010).

In a similar manner, the literature has suggested that $\mathrm{CV}$ is formed by the customer's past experiences (Voima et al. 2010). A multitude of questions arise regarding this first approach to value-in-life. A first step could be to explore the relevant construct, thus, we propose exploratory research. Similarly, creating value becomes a challenge when parts of the value formation process are invisible. Clearly, deep customer insights need to be accumulated for doing so. We proposed further integrating the customer into the company's processes, and hence, determining his/her desires in case they change. Similarly, how to deepen the relationships to customers might be a fruitful way for future research. Nevertheless, no research has appeared regarding this issue due to its novelty. Thus, we suggest that tackling this issue is a fruitful and informing approach.

Closely aligned to the importance of the accumulated experiences of customers is the dynamic nature of CV. As researchers have started to acknowledge the increasingly fast changing needs of customers, the research stream regarding the dynamic nature of $\mathrm{CV}$ calls for further enhancement. Hence, the whole area of $\mathrm{CV}$ dynamics constitutes a broad avenue for future research (Blocker and Flint 2007b). This is underpinned, as the inherent dynamism of $\mathrm{CV}$ is emphasized by both logics (Heinonen et al. 2010). Scholars may consider longitudinal approaches for evaluating how changes in what customers value affect a company's strategic orientation and competitive advantage (Zhou et al. 2008).

As pointed out, a multitude of network actors need to be considered on the supplier- and customer side (Cova and Salle 2008a, b). This leverages the challenges of current considerations. In the future, practitioners and researchers alike need to take this into account, as ignoring this shift would mislead companies in the decision-making process 
and would result in imperfect $\mathrm{CV}$ constructs. Thus, the social context enters questions like: Who is the value creator? What are the specific roles within value creation? We also suggest other disciplines than marketing to tackle this issue and strongly emphasize the value of interdisciplinary research. For example, integrating the literature on organizational or inter-organizational capabilities might enhance the CV literature in this point. Therefore, we suggest to closely connect notions from fields like strategy (DeSarbo et al. 2010; Priem 2007) and sociology (for instance regarding social network considerations on $\mathrm{CV}$, e.g., Edvardsson et al. 2011) to the CV literature. This may also result in a clearer picture of $\mathrm{CV}$ and its creation. Thus, we re-emphasize conducting interdisciplinary research to determine valuable approaches for enhancing knowledge regarding the creation of CV.

In summary, we recommend that future studies place emphasis on the external environment and the past customer experiences in regard to assessing CV. As empirical work is still broadly missing, scholars might engage in this regarding the proposed topics. In addition, inter-disciplinary research from fields such as strategy and sociology might further advance the $\mathrm{CV}$ concept.

\section{References}

Alderson W (1957) Marketing behavior and executive action: a functionalist approach to marketing theory. Richard D. Irwin, Homewood

Babin BJ, Darden WR, Griffin M (1994) Work and/or fun: measuring hedonic and utilitarian shopping value. J Consum Res 20(4):644-656

Ballantyne D, Varey RJ (2006) Creating value-in-use through marketing interaction: the exchange logic of relating, communicating and knowing. Mark Theory 6(3):335-348

Beverland M, Lockshin L (2003) A longitudinal study of customers' desired value change in business-to-business markets. Ind Mark Manag 32(8):653-666

Beverland M, Lockshin L (2004) A four-stage evolutionary model of customers' desired value change in business markets. In: Cron W, Low G (eds) AMA winter educator's conference: marketing theory and applications, Scottsdale. American Marketing Association, pp 134-135

Blocker CP (2011) Modeling customer value perceptions in cross-cultural business markets. J Bus Res 64(5):533-540

Blocker CP, Flint DJ (2007a) Customer segments as moving targets: Integrating customer value dynamism into segment instability logic. Ind Mark Manag 36(6):810-822

Blocker CP, Flint DJ (2007b) Exploring the dynamics of customer value in cross-cultural business relationships. J Bus Ind Mark 22(4):249-259

Brodie RJ (2009) From goods to service branding. Mark Theory 9(1):107-111

Brodie RJ, Whittome JRM, Brush GJ (2009) Investigating the service brand: a customer value perspective. J Bus Res 62(3):345-355

Cleland AS, Bruno AV (1996) The market value process: bridging customer and shareholder value. Jossey-Bass Publishers, San Francisco
Cova B, Pace S (2006) Brand community of convenience products: new forms of customer empowerment-the case "my Nutella The Community". Eur J Mark 40(9/10):1087-1105

Cova B, Salle R (2008a) Creating superior value through network offerings. Creating superior customer value. Adv Bus Mark Purch $14: 317-342$

Cova B, Salle R (2008b) Marketing solutions in accordance with the SD logic: co-creating value with customer network actors. Ind Mark Manag 37(3):270-277

Cretu AE, Brodie RJ (2007) The influence of brand image and company reputation where manufacturers market to small firms: a customer value perspective. Ind Mark Manag 36(2):230-240

Dawar N, Parker P (1994) Marketing universals: consumers' use of brand name, price, physical appearance, and retailer reputation as signals of product quality. J Mark 58(2):81-95

DeSarbo WS, Ebbes P, Fong DKH, Snow CC (2010) Revisiting customer value analysis in a heterogeneous market. J Model Manag $5(1): 8-24$

Drucker PF (1974) Management: tasks, responsibilities, practices. Heinemann, London

Edvardsson B, Gustafsson A, Kristensson P, Witell L (2010) Customer integration in service innovation. In: Gallouj F, Djellal F (eds) The handbook of innovation and services: a multi-disciplinary perspective. Edward Elgar Publishing Limited, Cheltenham, pp 301-317

Edvardsson B, Tronvoll B, Gruber T (2011) Expanding understanding of service exchange and value co-creation: a social construction approach. J Acad Mark Sci 39(2):327-339

Erdem T, Swait J (1998) Brand equity as a signaling phenomenon. J Consum Psychol 7(2):131-157

Flint DJ, Woodruff RB (2001) The initiators of changes in customers' desired value: results from a theory building study. Ind Mark Manag 30(4):321-337

Flint DJ, Woodruff RB, Gardial SF (2002) Exploring the phenomenon of customers' desired value change in a business-to-business context. J Mark 66(4):102-117

Gale BT (1994) Managing customer value. The Free Press, New York

Gallarza MG, Gil Saura I (2006) Value dimensions, perceived value, satisfaction and loyalty: an investigation of university students' travel behavior. Tourism Manag 27(3):437-452

Graf A, Maas P (2008) Customer value from a customer perspective: a comprehensive review. J Betr 58(1): 1-20

Grayson K (2007) Friendship versus business in marketing relationships. J Mark 71(4):121-139

Grieve K, Ortiz E (2003) Customer value management sins can be costly. DM Rev 13(11):38-40

Grönroos C (1997) Value-driven relational marketing: from products to resources and competencies. J Mark Manag 13(5):407-419

Grönroos C (2008) Service logic revisited: who creates value? And who co-creates? Eur Bus Rev 20(4):298-314

Grönroos C (2009) Marketing as promise management: regaining customer management for marketing. J Bus Ind Mark 24(5/6):351-359

Grönroos C (2011) A service perspective on business relationships: the value creation, interaction and marketing interface. Ind Mark Manag 40(2):240-247

Grönroos C, Ravald A (2009) Marketing and the logic of service: value facilitation, value creation and co-creation, and their marketing implications. Hanken School of Economics, Helsinki

Grönroos C, Ravald A (2011) Service as business logic: implications for value creation and marketing. J Serv Manag 22(1):5-22

Gummesson E (2008) Extending the service-dominant logic: from customer centricity to balanced centricity. J Acad Mark Sci 36(1):15-17 
Gummesson E, Lusch RF, Vargo SL (2010) Transitioning from service management to service-dominant logic: Observations and recommendations. Int J Qual Serv Sci 2(1):8-22

Heinonen K, Strandvik T, Mickelsson K-J, Edvardsson B, Sundström E, Andersson P (2009) Rethinking service companies' business logic: do we need a customer-dominant logic as a guideline? Hanken School of Economics, Helsinki

Heinonen K, Strandvik T, Mickelsson K-J, Edvardsson B, Sundström E, Andersson P (2010) A customer-dominant logic of service. J Serv Manag 21(4):531-548

Henneberg SC, Mouzas S (2008) Final customers' value in business networks. In: Woodside A, Golfetto F, Gibbert M (eds) Creating and managing superior customer value, vol 14. 1 edn. Emerald Group Publishing Limited, Bingley, pp 99-127

Hirschmann E, Holbrook M (1982) Hedonic consumption: emerging concept, methods and perceptions. J Mark 46(3):92-101

Holbrook MB (1994) The nature of customer value: an axiology of services in the consumption experience. In: Rust RT, Oliver RL (eds) Service quality: new directions in theory and practice. Sage Publications, Thousand Oaks, pp 21-71

Holbrook MB (2005) Customer value and autoethnography: subjective personal introspection and the meanings of a photograph collection. J Bus Res 58(1):45-61

Holbrook MB (2006) Consumption experience, customer value, and subjective personal introspection: an illustrative photographic essay. J Bus Res 59(6):714-725

Howden C, Pressey AD (2008) Customer value creation in professional service relationships: the case of credence goods. Serv Ind J 28(6):789-812

Huber F, Herrmann A, Morgan RE (2001) Gaining competitive advantage through customer value oriented management. J Consum Mark 18(1):41-53

Khalifa AS (2004) Customer value: a review of recent literature and an integrative configuration. Manage Decis 42(5):645-666

Kortge GD, Okonkwo PA (1993) Perceived value approach to pricing. Ind Mark Manag 22(2):133-140

Kothandaraman P, Wilson DT (2001) The future of competition: valuecreating networks. Ind Mark Manag 30(4):379-389

Lapierre J (2000) Customer-perceived value in industrial contexts. J Bus Ind Mark 15(2/3):122-145

Levitt T (1986) The marketing imagination. The Free Press, New York

Lindgreen A, Wynstra F (2005) Value in business markets: What do we know? Where are we going? Ind Mark Manag 34(7):732-748

Lusch RF, Vargo SL (2006a) Service-dominant logic as a foundation for a general theory. In: Lusch RF, Vargo SL (eds) The servicedominant logic of marketing: dialog, debate, and directions. M.E. Sharpe, Armonk, pp 406-420

Lusch RF, Vargo SL (2006b) Service-dominant logic: reactions, reflections and refinements. Mark Theory 6(3):281

Lusch RF, Vargo SL, O'Brien M (2007) Competing through service: Insights from service-dominant logic. J Retail 83(1):5-18

Lusch RF, Vargo SL, Tanniru M (2010) Service, value networks and learning. J Acad Mark Sci 38(1):19-31

Madhavaram S, Hunt SD (2008) The service-dominant logic and a hierarchy of operant resources: developing masterful operant resources and implications for marketing strategy. J Acad Mark Sci 36(1):67-82

Marketing Science Institute (2011) 2010-2012 Research priorities. Marketing science institute MSI. Accessed 15 March 2011

Mathwick C, Malhotra NK, Rigdon E (2002) The effect of dynamic retail experiences on experiential perceptions of value: an internet and catalog comparison. J Retail 78(1):51-60

Matzler K (2000) Customer value management. Unternehmung 54(4):289-308
McDougall GHG, Levesque T (2000) Customer satisfaction with services: putting perceived value into the equation. J Serv Mark 14(5):392-410

Mele C, Spena TR, Colurcio M (2010) Co-creating value innovation through resource integration. Int J Qual Serv Sci 2(1):60-78

Merz MA, He Y, Vargo SL (2009) The evolving brand logic: a servicedominant logic perspective. J Acad Mark Sci 37(3):328-344

Möller KS (2001) Information categories and editorial processes in multiple channel publishing. Royal Institute of Technology, KTH, Sweden (Citeseer)

Möller K (2006) Role of competences in creating customer value: a value-creation logic approach. Ind Mark Manag 35(8):913-924

Nasution HN, Mavondo FT (2008) Customer value in the hotel industry: What managers believe they deliver and what customer experience. Int J Hosp Manag 27(2):204-213

Normann R, Ramirez R (1993) Designing interactive strategy. Harvard Business Review 71(4):65-77

Parasuraman A (1997) Reflections on gaining competitive advantage through customer value. J Acad Mark Sci 25(2):154-161

Payne A, Holt S (2001) Diagnosing customer value: integrating the value process and relationship marketing. Brit $\mathrm{J}$ Manag 12(2):159-182

Payne AF, Storbacka K, Frow P (2008) Managing the co-creation of value. J Acad Mark Sci 36(1):83-96

Payne A, Storbacka K, Frow P, Knox S (2009) Co-creating brands: Diagnosing and designing the relationship experience. J Bus Res 62(3):379-389

Porter ME (1996) What's strategy. Harvard Bus Rev 74(5-6):61-78

Prahalad CK, Ramaswamy V (2004a) Co creation experiences: the next practice in value creation. J Interact Mark 18(3):5-14

Prahalad CK, Ramaswamy V (2004b) The future of competition: cocreating unique value with customers. Harvard Business School Press

Priem RL (2007) A consumer perspective on value. Acad Manag Rev 32(1):219-235

Ravald A, Grönroos C (1996) The value concept and relationship marketing. Eur J Mark 30(2):19-30

Sandström S, Edvardsson B, Kristensson P, Magnusson P (2008) Value in use through service experience. Manag Serv Qual 18(2):112-126

Shah D, Rust RT, Parasuraman A, Staelin R, Day GS (2006) The path to customer centricity. J Serv Res-US 9(2):113-125

Smith JB, Colgate M (2007) Customer value creation: a practical framework. J Mark Theory Pract 15(1):7-23

Srivastava RK, Fahey L, Christensen HK (2001) The resource-based view and marketing: the role of market-based assets in gaining competitive advantage. J Manag 27(6):777

Srivastava V, Singh T (2010) Value creation through relationship closeness. J Strateg Mark 18(1):3-17

Strandvik T, Rindell A (2010) Value of image in service. Hanken School of Economics, Helsinki

Sweeney JC, Soutar GN (2001) Consumer perceived value: the development of a multiple item scale. J Retail 77(2):203-220

The American Marketing Association Board of Directors (2007) Definition of Marketing. The American Marketing Association Board of Directors. http://www.marketingpower.com/AboutAMA/ Pages/DefinitionofMarketing.aspx. Accessed 19 March 2011

Tynan C, McKechnie S, Chhuon C (2010) Co-creating value for luxury brands. J Bus Res 63(11):1156-1163

Ulaga W (2003) Capturing value creation in business relationships: a customer perspective. Ind Mark Manag 32(8):677-693

Ulaga W, Eggert A (2005) Relationship value in business markets: the construct and its dimensions. J Bus-Bus Mark 12(1):73-99

Ulaga W, Eggert A (2006a) Relationship value and relationship quality: broadening the nomological network of business-to-business relationships. Eur J Mark 40(3/4):311-327 
Ulaga W, Eggert A (2006b) Value-based differentiation in business relationships: gaining and sustaining key supplier status. J Mark 70(1):119-136

Vandermerwe S (1996) New competitive spaces: jointly investing in new customer logic. Columbia J World Bus 31(4):80-101

Vargo SL, Lusch RF (2004) Evolving to a new dominant logic for marketing. J Mark 68(1):1-17

Vargo SL, Lusch RF (2006) Service-dominant logic: what it is, what it is not, what it might be. In: Lusch RF, Vargo SL (eds) The servicedominant logic of marketing: dialog, debate, and directions. ME Sharpe, Armonk, pp 43-56

Vargo SL, Lusch RF (2008a) Service-dominant logic: continuing the evolution. J Acad Mark Sci 36(1):1-10

Vargo SL, Lusch RF (2008b) Why "service"? J Acad Mark Sci 36(1):25-38

Vargo SL, Maglio PP, Akaka MA (2008) On value and value co-creation: a service systems and service logic perspective. Eur Manag J 26(3):145-152

Voima P, Heinonen K, Strandvik T (2010) Exploring customer value formation: a customer dominant logic perspective. Hanken School of Economics Working Papers. Hanken School of Economics, Helsinki
Wikner S (2010) Value co-creation as practice. Dissertation, Jönköping International Business School, Jönköping

Wong YH, Chan RYK, Leung TKP (2005) Managing information diffusion in internet marketing. Eur J Mark 39(7/8):926-946

Woodruff RB (1997) Customer value: the next source for competitive advantage. J Acad Mark Sci 25(2):139-153

Woodruff RB, Flint DJ (2006) Marketing's service-dominant logic and customer value. In: Lusch RF, Vargo SL (eds) The servicedominant logic of marketing: dialog, debate, and directions. M.E. Sharpe, Armonk, pp 183-195

Wuyts S, Geyskens I (2005) The formation of buyer-supplier relationships: detailed contract drafting and close partner selection. J Mark 69(4):103-117

Zeithaml VA (1988) Consumer perceptions of price, quality, and value: a means-end model and synthesis of evidence. J Mark $52(3): 2-22$

Zhou KZ, Li JJ, Zhou N, Su C (2008) Market orientation, job satisfaction, product quality, and firm performance: evidence from China. Strateg Manag J 29(9):985-1000 